American Journal of Applied Sciences 6 (3): 498-506, 2009

ISSN 1546-9239

(C) 2009 Science Publications

\title{
Soil Quality of Die off and Die Back Mangrove Grown at Al-Jubail Area (Saudi Arabia) of the Arabian Gulf
}

\author{
${ }^{1}$ Akram Ali, ${ }^{1}$ Ahmed Alfarhan, ${ }^{2}$ Ernest Robinson and ${ }^{3}$ Wafa Altesan \\ ${ }^{1}$ Department of Botany and Microbiology, College of Science, King Saud University, \\ Riyadh 11451, PO Box: 2455, KSA \\ ${ }^{2}$ King Khalid Wildlife Research Centre, Thumamah, C/o. National Commission for Wildlife \\ Conservation and Development, P.O. Box 61681, Riyadh 11575, KSA \\ ${ }^{3}$ Depatment of Botany, College of Science, King Faisal Univ., Damam 31113, PO Box: 838, KSA
}

\begin{abstract}
The declining mangrove vegetation along the Arabian Gulf coast necessitates a thorough study for finding out the soil status and for rehabilitating the affected population. In this study, soil supporting die back/die off mangrove plants at Al-Jubail area was studied. Field experiments were also conducted to determine the success/failure ratio of the germinated seeds in both healthy and damaged soils. Obtained results showed that high damage was in the soil of sand mound sites because only $19 \%$ of mangrove fresh seeds could germinate in this site, while low damage was recorded in the soil of inter-tidal sites where germination rate was about $32 \%$. High decrease in $\mathrm{C}_{\mathrm{TMB}}$ was noticed at the intertidal sites compared to other damaged sites, while no significant differences were noticed between all damaged sites in $\mathrm{C}_{\mathrm{AMB}}$, $\mathrm{BR}$ and DEA. Compared to controlled conditions, values of all anions were significantly high at all studied sites. Values of all major and minor elements at all damaged sites were also significantly high compared to controlled conditions. This study concluded that soils with higher quality were degraded more rapidly, because they usually need more nutrient input to maintain their quality status than those with lower quality. These analyses show that it is of equal importance to improve soil quality in degraded locations and to sustain it in high-quality areas.
\end{abstract}

Key words: SQ parameters, Avicennia marina, Saudi Arabia, seed germination, SQI, the Arabian Gulf

\section{INTRODUCTION}

The mangrove [Avicennia marina (Forsk.) Vierh] is the highly adapted plants found in the tropical intertidal forest communities or the ecosystem itself ${ }^{[32]}$. Mangrove plants are diverse group of predominantly trees, shrubs, palms and ground ferns growing around the mean sea level in the marine intertidal zone along tropical and subtropical coasts ${ }^{[20]}$. The ecological functions of mangroves as land builder and coastline stabilizer are well known ${ }^{[33,38]}$. It is also known that mangroves are highly productive and provide suitable habitats, shelter, breeding sites and food source for various groups of fish and other coastal wildlife ${ }^{[37]}$.

Huge areas of mangrove forests have been lost from Southeast Asia due to population expansion and human activities such as wood extraction, conversion to aquaculture and agriculture, salt production, mining and pollution from coastal industrialization and urbanization $^{[19]}$. The development of aquaculture represents a major threat to mangrove ecosystems and is generally affecting the characters of the soil of these habitats. The damage of soil leads to weaken the growth of existing plants ${ }^{[39]}$. The mangrove forest in Malaysia decreased $60 \%$ in Philippines, $55 \%$ in Thailand, $37 \%$ in Vietnam and $75 \%$ in Sulawesi, Indonesia ${ }^{[26]}$. An estimated $30 \%$ of Malaysian mangrove forest has been destroyed because of expanding shrimp farms ${ }^{[26]}$.

Numerous researchers have conducted field surveys, observations and field and laboratory experiments to examine the factors influencing mangrove soil quality. These factors include: water and soil sulfide concentrations ${ }^{[21,25]}$, salinity ${ }^{[5,38]}$, anoxia and water logging ${ }^{[37,38]}$, $\operatorname{light}^{[34,38]}$, nutrient availability ${ }^{[23,38]}$; and biotic interactions such as site-specific competition $^{[4]}$ and predation ${ }^{[11,21,22]}$.

The Soil Quality (SQ) is a minimum dataset (MDS) of analytical biological, chemical and physical properties of field moist and air-dried soils. Assessments of SQ focus on how a soil functions with respect to specific land-use, crop-production and environmental questions ${ }^{[27]}$. Researchers have recently

Corresponding Author: Akram Ali, Department of Botany, Faculty of Science, Zagazig University, Zagazig, Egypt

Tel: 00966557554020 Fax: 0096614675833 
begun to focus on the role of SQ in a sustainable agriculture ${ }^{[13]}$. A high quality soil is thought to include the elements of efficient biological activity, improved soil aggregation, enhanced water holding capacity, rapid infiltration, increased nutrients availability, extensive rooting depth, increased soil organic matter, reduced pesticide leaching and resistance to compaction $^{[42]}$. The soil quality index (SQI) was able to classify and compare the functional capacity of soils among different stress systems ${ }^{[29]}$. Also, the SQI clearly demonstrated the differences among the soils with different biological, chemical and physical properties and subjected to different practices ${ }^{[32]}$. The SQI may be useful as a report card to evaluate whether a soil is improving, sustaining or degrading in quality ${ }^{[8]}$.

This study is conducted to identify some of the soil quality factors present at Al-Jubail Area. We selected some soil factors (biological and chemical) as soil quality indicators for regional-scale assessment and for determining SQI of mangrove soil.

\section{MATERIALS AND METHODS}

Study area: The Arabian Gulf region extends from Shatt Al-Arab and the coastal lowlands in the north to the Strait of Hormus and the high mountains of Oman in the south. It is a semi enclosed shallow continental water body measuring $1000 \mathrm{~km}$ in the length and varying in width from a maximum of 340 to a min of 60 $\mathrm{kms}$. The average depth is about $35 \mathrm{~m}$ and maximum is $100 \mathrm{~m}$. The Gulf is subjected to wide climatic fluctuations, with surface water temperatures generally ranging from $12^{\circ} \mathrm{C}$ in winter to $>35^{\circ} \mathrm{C}$ in summer and salinity from $28-60 \mathrm{ppt}$. The Gulf is home to one of the world's largest dugong populations, found off the coasts of Saudi Arabia.

Al -Jubail area is part of the coast of Saudi Arabia in the Arabian Gulf. It encompasses extensive mangroves, mudflats and a diverse array of benthic habitats including reefs and sea grasses. There are reefs which mostly appear as small pinnacles or outcrops and as patch reefs between Ras Almishab Saffaniyah and Abu Ali and between Abu Ali and Ras Tanura. These reefs support coral growth at their extreme northern distribution, which are remarkable as they withstand the major shifts in temperature and salinity occurring in the Gulf. The area is also, an important avifaunal wintering site and migratory pathway, with extensive shallow water bodies.

Testing mangrove trees status and its soil: Mangrove [Avicennia marina (Forsk.) Vierh] trees flourish in sand mound, salt flat, shoreline and intertidal sites at Al-
Jubail Area. Die off/die back/healthy mangrove plants were counted in three quadrates, each with an area of $10 \times 10 \mathrm{~m}^{2}$. Hundred fresh seeds of Mangroves were sown in the soils of each site and left them for four months under all conditions of the Arabian Gulf; and then counted the number of germinated seeds in each site.

Measurement of soil quality indicators: Soils supporting die-off, die-back and healthy plants from sand mound, salt flat, shoreline and intertidal sites were collected and transferred to laboratory, then it is subjected to the biochemical properties, soluble cations and anions and major and minor elements of the soil were measured as a minimum dataset of soil (MDS) to quantify soil quality (SQ).

Biochemical properties: Total microbial biomass $\left(\mathrm{C}_{\mathrm{TMB}}\right)\left(\mathrm{M} \mathrm{CO}_{2}-\mathrm{C} \mathrm{m}^{-3}\right)$ was measured by the carbon field index (CFI) method ${ }^{[17,18]}$. Active microbial biomass $\left(\mathrm{C}_{\mathrm{AMB}}\right)\left(\mathrm{M} \mathrm{CO}_{2}-\mathrm{C} \mathrm{m}^{-3}\right)$ of soil was measured by the stimulated basal respiration method ${ }^{[17,40]}$. Basal respiration (BR) $\left(\mathrm{M} \mathrm{CO}_{2}-\mathrm{C} \mathrm{m}^{-3}\right.$ day $\left.^{-1}\right)$ was measured as the average $\mathrm{CO}_{2}$-evolution of $2 \mathrm{~mm}$ sieved nonamended homogenized soil (unfumigated) after an incubation period of 10 days ${ }^{[17]}$. Arginine ammonification (ARG) rate $\left(\mathrm{mM} \mathrm{NH}_{4} \mathrm{~m}^{-3} \mathrm{~h}^{-1}\right)$ was measured by the method of Alef and Kleiner ${ }^{[1]}$. Dehydrogenase enzyme activity (DEA) (M TPF day ${ }^{-1}$ $\mathrm{m}^{-3}$ ) was determined by the method of Tabatabai ${ }^{[35]}$. A number of metabolic quotients (qR), such as $\mathrm{C}_{\mathrm{TMB}} \mathrm{C}_{\mathrm{org}}{ }^{-1}$, $\mathrm{C}_{\mathrm{AMB}} \mathrm{C}_{\text {org }}{ }^{-1}$ and $\mathrm{C}_{\mathrm{AMB}} \mathrm{C}_{\mathrm{TMB}}$ were calculated ${ }^{[17]}$. The specific maintenance respiration rate $\left(\mathrm{qCO}_{2}\right)$ was calculated as mean daily $\mathrm{BR} \mathrm{C}_{\mathrm{TMB}}\left(\mathrm{M} \mathrm{CO}_{2}-\mathrm{C}\right.$ day $^{-1}$ $\mathrm{C}_{\mathrm{TMB}}{ }^{-1}$ ) by the method of Anderson and Gray ${ }^{[3]}$.

Soluble cations and anions: Soluble cations and soluble anions were determined as the method described by Richards ${ }^{[30]}$.

Major and minor elements: Phosphorus in soil was determined as available phosphorus in $0.002 \mathrm{NH}_{2} \mathrm{SO}_{4}$ extracts using Spectro Master model 410, Taiwan. Total calcium, magnesium, sodium and potassium were determined by Jenway flamephotometer PFP7, England. The remaining elements (S, Fe, $\mathrm{Mn}, \mathrm{Zn}, \mathrm{Cu}$ ) were determined using Perkin Elmer atomic absorption 3110, USA.

Mathematical derivation of soil quality index: This approach allowed normalization of selected measured biological and chemical properties of soil, combined together and then averaged into a single integrator of 
SQ. The description of the inductive additive approach that was modified to use for mathematical derivation of SQI's from measured soil properties was found in the method of Humphreys and Wilkinson ${ }^{[16]}$.

Statistical analysis: Calculations and statistical analysis of MDS-SQ and SQI's were done, using the SPSS $^{\circledR}$ BASE 10.0 (SPSS Inc., Chicago, IL) packages. SQI were tested using ANOVA. LSD separated means at $\mathrm{p}<0.05$ levels was used. Mean separation between individual sites as replications.

\section{RESULTS AND DISCUSSION}

Healthy/die off/die back mangrove: The percentages of healthy, die off and die back plants and germinated seeds in the soil supporting mangroves at Al-Jubail area, are presented in Table 1. These data showed that the number of healthy mangroves per quadrate were higher in sand mound, shoreline and intertidal sites than salt flat site. Gradual decreases in the number of die off plants from sand mound to intertidal sites, while another gradual decreases in the number of die back plants from intertidal to sand mound sites. High damage in the soil of sand mound sites is because only $19 \%$ of mangrove fresh seed could germinate in this site, while low damage was recorded in soil of intertidal sites which was about $32 \%$.

\section{Effect of mangrove soil characters on its quality indices}

Biochemical properties: Table 2 showed mean values of selected biochemical characters as soil quality indicators to the soil supporting mangroves at Al-Jubail Area. Significant differences are noticed in for all biochemical characters of soil between healthy soil (control) and different sites (damaged) except qR's and $\mathrm{qCO}_{2}$. High decrease in $\mathrm{C}_{\text {тмв }}$ was observed at intertidal sites compared to other damaged sites, while no significant differences between all damaged sites in $\mathrm{C}_{\mathrm{AMB}}$, $\mathrm{BR}$ and DEA. Arginine ammonification enzyme activity (ARG) recorded significant difference between salt flat and intertidal sites of all damaged soils.

Soil quality indices based on selected biochemical characters for soils supporting mangroves at Al-Jubail Area are given in Table 3. The data showed that significant decreases in SQI's $\left(\mathrm{SQI}_{\mathrm{T}}=\right.$ Soil quality index based on all soil properties, $\mathrm{SQI}_{7}=$ Soil quality index based on all soil properties except enzymes, $\mathrm{SQI}_{3}$ $=$ Soil quality index based on $\mathrm{C}_{\mathrm{TMB}}, \mathrm{C}_{\mathrm{AMB}}$ and $\mathrm{BR}, \mathrm{SQI}_{(3)}$ $=$ Soil quality index based on qR's, $\mathrm{SQI}_{2}=$ Soil quality index based on enzymes, $\mathrm{SQI}_{1}=$ Soil quality index based on $\mathrm{C}_{\mathrm{TMB}}, \mathrm{SQI}_{(1)}=$ Soil quality index based on $\mathrm{C}_{\mathrm{AMB}}$ ) of all damaged sites in comparison with healthy soils. The $\mathrm{SQI}_{3}, \mathrm{SQI}_{1}, \mathrm{SQI}_{(1)}$ indicated that less quality soils of damaged sites than other calculated indices $\left(\mathrm{SQI}_{\mathrm{T}}, \mathrm{SQI}_{7}, \mathrm{SQI}_{(3)}, \mathrm{SQI}_{2}\right)$. No significant differences between soil quality indices of damaged sites $\left(\mathrm{SQI}_{7}\right.$, $\left.\mathrm{SQI}_{3}, \mathrm{SQI}_{(3)}, \mathrm{SQI}_{(1)}\right)$. The calculated SQI based on $\mathrm{C}_{\mathrm{TMB}}$ and $\mathrm{C}_{\mathrm{AMB}}$ was the best indictor for soil quality status at Al-Jubail Area.

Soluble cations and anions: Data of soluble cations and anions (\%) as soil quality indicators are presented in Table 4. High changes are recorded in all soluble

Table 1: Mean values of percentage numbers of healthy, die off and die back plants and germinated seeds number to the soil supporting mangroves at Al-Jubail area, KSA

\begin{tabular}{lllll}
\hline Sites & \% of healthy & \% of Die off plants/quadrate & \% of die back plants/quadrate & \% of germinated seeds/quadrate \\
\hline Sand mound & 55 & 35 & 14 & 19 \\
Salt flat & 34 & 25 & 27 & 22 \\
Shoreline & 66 & 10 & 35 & 33 \\
Intertidal & 70 & 4 & 36 & 32 \\
LSD $<0.5$ & 14 & 12 & 7 & 9 \\
\hline
\end{tabular}

Table 2: Mean values of selected biochemical characters as soil quality indicators to the soil supporting mangroves at Al-Jubail area, KSA.

\begin{tabular}{|c|c|c|c|c|c|c|c|c|c|}
\hline Sites & $\begin{array}{l}\mathrm{C}_{\mathrm{TMB}} \\
\left(\mathrm{M} \mathrm{CO}_{2} \mathrm{~m}^{-3}\right)\end{array}$ & $\begin{array}{l}\mathrm{C}_{\mathrm{AMB}} \\
\left(\mathrm{M} \mathrm{CO}_{2} \mathrm{~m}^{-3}\right)\end{array}$ & $\begin{array}{l}\mathrm{qR}(\%) \\
\mathrm{C}_{\mathrm{TMB}} \mathrm{C}_{\mathrm{ORG}}{ }^{-1}\end{array}$ & $\begin{array}{l}\mathrm{qR}(\%) \\
\mathrm{C}_{\mathrm{AMB}} \mathrm{C}_{\mathrm{ORG}}^{-1}\end{array}$ & $\begin{array}{l}\mathrm{qR}(\%) \\
\mathrm{C}_{\mathrm{TMB}} \mathrm{C}_{\mathrm{AMB}}{ }^{-1}\end{array}$ & $\begin{array}{l}\mathrm{BR}\left(\mathrm{M} \mathrm{CO}_{2}\right. \\
\left.\mathrm{d}^{-1} \mathrm{~m}^{-3}\right)\end{array}$ & $\begin{array}{l}\mathrm{qCO}_{2}\left(\mathrm{M} \mathrm{CO}_{2}\right. \\
\left.\mathrm{d}^{-1} \mathrm{C}_{\mathrm{TMB}}^{-1}\right)\end{array}$ & $\begin{array}{l}\text { ARG }\left(\mathrm{mM} \mathrm{NH}_{4}\right. \\
\left.\mathrm{hr}^{-1} \mathrm{~m}^{-3}\right)\end{array}$ & $\begin{array}{l}\operatorname{DEA}(\mathrm{M} \\
\left.\operatorname{TPF~d}^{-1} \mathrm{~m}^{-3}\right)\end{array}$ \\
\hline Control & 7.12 & 3.01 & 4.12 & 1.66 & 38.41 & 1.42 & 0.16 & 21.22 & 0.15 \\
\hline Sand mound & 3.32 & 0.88 & 1.77 & 0.92 & 27.98 & 0.88 & 0.35 & 13.00 & 0.06 \\
\hline Salt flat & 2.56 & 0.99 & 1.78 & 0.92 & 28.12 & 0.88 & 0.36 & 15.23 & 0.06 \\
\hline Shoreline & 1.99 & 0.88 & 1.66 & 0.89 & 27.53 & 0.86 & 0.33 & 10.12 & 0.05 \\
\hline Intertidal & 1.11 & 0.88 & 1.17 & 0.91 & 27.99 & 0.75 & 0.38 & 10.05 & 0.05 \\
\hline $\operatorname{LSD}_{\mathrm{P}<0.5}$ & 0.19 & 0.12 & 3.01 & 0.62 & 2.11 & 0.11 & 0.21 & 5.12 & 0.05 \\
\hline
\end{tabular}

Control site means soil supporting healthy mangrove trees, other sites means soil supporting die off/die back mangrove trees. $\mathrm{C}_{\mathrm{TMB}}=\mathrm{Total}$ microbial biomass $\mathrm{C}, \mathrm{C}_{\mathrm{AMB}}=$ Active microbial biomass $\mathrm{C}, \mathrm{qR}=$ Metabolic quotients, $\mathrm{C}_{\mathrm{ORG}}=$ Total soil organic $\mathrm{C}, \mathrm{BR}=\mathrm{Basal}_{\text {respiration, }} \mathrm{qCO} \mathrm{C}_{2}=$

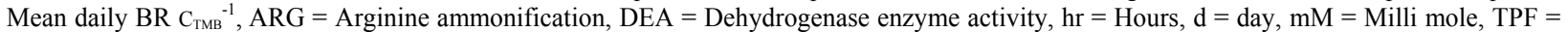
Triphenyl formazen, $\mathrm{LSD}=$ Least significant difference and $\mathrm{p}=$ probability 
Am. J. Applied Sci., 6 (3): 498-506, 2009

Table 3: Mean values of soil quality indices based on selected biochemical characters as soil quality indicators to the soil supporting mangroves at Al-Jubail area, KSA

\begin{tabular}{llllllll}
\hline Sites & $\mathrm{SQI}_{\mathrm{T}}$ & $\mathrm{SQI}_{7}$ & $\mathrm{SQI}_{3}$ & $\mathrm{SQI}_{(3)}$ & $\mathrm{SQI}_{2}$ & $\mathrm{SQI}_{1}$ & $\mathrm{SQI}_{(1)}$ \\
\hline Control & 1.00 & 1.00 & 1.00 & 1.00 & 1.00 & 1.00 & 1.00 \\
Sand mound & 0.64 & 0.65 & 0.44 & 0.71 & 0.61 & 0.47 & 0.28 \\
Salt flat & 0.66 & 0.64 & 0.38 & 0.72 & 0.72 & 0.36 & 0.33 \\
Shoreline & 0.57 & 0.61 & 0.32 & 0.71 & 0.47 & 0.28 & 0.28 \\
Intertidal & 0.43 & 0.59 & 0.23 & 0.71 & 0.51 & 0.16 & 0.28 \\
LSD $P<0.5$ & 0.14 & 0.12 & 0.11 & 0.19 & 0.14 & 0.15 & 0.07 \\
\hline
\end{tabular}

Control site means soil supporting healthy mangrove trees, other sites means soil supporting die off/die back mangrove trees. SQI $=\mathrm{S}_{\mathrm{T}}$ Soil quality index based on all soil properties, $\mathrm{SQI}_{7}=$ Soil quality index based on all soil properties except enzymes, $\mathrm{SQI}_{3}=$ Soil quality index based on $\mathrm{C}_{\mathrm{TMB}}$, $\mathrm{C}_{\mathrm{AMB}}$ and $\mathrm{BR}, \mathrm{SQI}_{(3)}=$ Soil quality index based on $\mathrm{qR}$ 's, $\mathrm{SQI}_{2}=$ Soil quality index based on enzymes, $\mathrm{SQI}_{1}=$ Soil quality index based on $\mathrm{C}_{\mathrm{TMB}}$, $\mathrm{SQI}_{(1)}=$ Soil quality index based on $\mathrm{C}_{\mathrm{AMB}}, \mathrm{LSD}=$ Least significant difference and $\mathrm{p}=$ probability

Table 4: Mean values of soluble cations and anions (\%) as soil quality indicators to the soil supporting mangroves at Aljubail area, KSA

\begin{tabular}{|c|c|c|c|c|c|c|c|c|c|c|}
\hline \multirow[b]{2}{*}{ Sites } & \multicolumn{6}{|c|}{ Soluble cations $(\%)$} & \multicolumn{4}{|c|}{ Soluble anions $(\%)$} \\
\hline & $\mathrm{Ca}^{++}$ & $\mathrm{Mg}^{++}$ & $\mathrm{K}^{+}$ & $\mathrm{Na}^{+}$ & $\mathrm{P}^{+++}$ & $\mathrm{S}^{++}$ & $\mathrm{Cl}^{-}$ & $\mathrm{SO}_{4}^{--}$ & $\mathrm{CO}_{3}{ }^{--}$ & $\mathrm{HCO}_{3}^{-}$ \\
\hline Control & 0.16 & 0.18 & 0.16 & 0.12 & 0.09 & 0.12 & 1.66 & 0.41 & 1.42 & 1.16 \\
\hline Sand mound & 0.31 & 0.34 & 0.39 & 1.91 & 0.14 & 0.60 & 2.82 & 0.55 & 2.26 & 1.36 \\
\hline Salt flat & 0.39 & 0.34 & 0.42 & 1.11 & 0.14 & 0.70 & 2.81 & 0.92 & 2.82 & 1.37 \\
\hline Shoreline & 1.65 & 0.64 & 1.43 & 1.82 & 1.55 & 0.70 & 3.98 & 2.28 & 2.44 & 1.95 \\
\hline Intertidal & 1.41 & 0.53 & 1.02 & 1.56 & 0.49 & 0.70 & 3.32 & 2.12 & 2.26 & 1.55 \\
\hline $\mathrm{LSD}_{P<0,5}$ & 0.23 & 0.16 & 0.27 & 0.11 & 0.10 & 0.21 & 0.32 & 0.13 & 0.16 & 0.81 \\
\hline
\end{tabular}

Control site means soil supporting healthy mangrove trees, other sites means soil supporting die off/die back mangrove trees. LSD $=$ Least significant difference and $\mathrm{p}=$ probability

cations content of all damaged sites except $\mathrm{Mg}^{++}$and $\mathrm{S}^{++}$, while little variations are in soluble anions content of all damaged sites except $\mathrm{SO}_{4}^{-}$. Significant high values of $\mathrm{Ca}^{++}, \mathrm{Mg}^{++}, \mathrm{K}^{+}$and $\mathrm{P}^{+++}$were noticed at shoreline and intertidal sites, while the values of $\mathrm{Na}^{++}$ and $\mathrm{S}^{++}$are higher at all damaged sites in comparison with controlled conditions. All anions are significantly high at all studied sites when compared to controlled conditions.

Mean values of soil quality indices (soluble cations and anions (\%) as soil quality indicators to the soil supporting mangroves at Al-Jubail Area are listed in (Table 5), showed high decrease in soil quality. Based on cations and anions content, close values of $\mathrm{SQI}_{\mathrm{T}}$ between sand mound and salt flat and between shoreline and intertidal sites were recorded. Significant increases in SQI of salt flat based on soluble cations content in compared to other damaged sites. Soil quality indices recorded higher values at sand mound being $68 \%$, salt flat being $23 \%$, salt flat being $11 \%$ and shoreline sites being $41 \%$ between damaged sites, based on soluble anions; $\mathrm{Ca}^{++}, \mathrm{K}^{+}$and $\mathrm{Na}^{+} ; \mathrm{Na}^{+}$and $\mathrm{K}^{+}$, respectively. Soil quality indices based on soluble cations and anions (\%) showed that $\mathrm{SQI}_{\mathrm{T}}$ and $\mathrm{SQI}_{1 *}$ are the best soil quality indicators.

Major and minor elements: Analysis of major elements showed that $\mathrm{Na}$ and $\mathrm{K}$ were the dominant elements followed by $\mathrm{Mg}, \mathrm{P}, \mathrm{Ca}$ and then $\mathrm{S}$, while minor elements showed that $\mathrm{Cu}$ was relatively higher
Table 5: Mean values of soil quality indices based on soluble cations and anions (\%) as soil quality indicators to the soil supporting mangroves at Al-Jubail area, KSA

\begin{tabular}{|c|c|c|c|c|c|c|}
\hline Sites & $\mathrm{SQI}_{\mathrm{T}}$ & $\mathrm{SQI}_{\mathrm{C}}$ & $\mathrm{SQI}_{\mathrm{A}}$ & $\mathrm{SQI}_{3}$ & $\mathrm{SQI}_{1}$ & $\mathrm{SQI}_{1}$ \\
\hline Control & 1.00 & 1.00 & 1.00 & 1.00 & 1.00 & 1.00 \\
\hline Sand mound & 0.52 & 0.22 & 0.68 & 0.19 & 0.03 & 0.41 \\
\hline Salt flat & 0.49 & 0.31 & 0.59 & 0.23 & 0.11 & 0.38 \\
\hline Shoreline & 0.30 & 0.11 & 0.44 & 0.09 & 0.07 & 0.11 \\
\hline Intertidal & 0.37 & 0.15 & 0.50 & 0.11 & 0.08 & 0.16 \\
\hline $\operatorname{LSD}_{\mathrm{P}<0.5}$ & 0.12 & 0.05 & 0.11 & 0.07 & 0.03 & 0.07 \\
\hline
\end{tabular}

Control site means soil supporting healthy mangrove trees, other sites means soil supporting die off/die back mangrove trees. $\mathrm{SQI}_{\mathrm{T}}=$ Soil quality index based on all soil properties, $\mathrm{SQI}_{\mathrm{C}}=$ Soil quality index based on all soil cations, $\mathrm{SQI}_{\mathrm{A}}=$ Soil quality index based on all soil anions, $\mathrm{SQI}_{3}=$ Soil quality index based on $\mathrm{Na}^{+}, \mathrm{Ca}^{++}$and $\mathrm{K}^{+}, \mathrm{SQI}_{1}=$ Soil quality index based on $\mathrm{Na}^{+}, \mathrm{SQI}_{1^{*}}=$ Soil quality index based on $\mathrm{K}^{+}, \mathrm{LSD}=$ Least significant difference and $\mathrm{p}=$ probability

than $\mathrm{Zn}$ followed by Fe and Mn (Table 6). Significant increases in all major and minor elements at all damaged sites compared to controlled conditions. No significant differences of $\mathrm{Ca}, \mathrm{Mg}$ and $\mathrm{S}$ are noticed among all damaged sites. Shoreline site exhibited the highest values of $\mathrm{Na}, \mathrm{K}$ and $\mathrm{P}$ among all damaged sites. Since high variations between damaged sites and control, we use them as the best quality indicators.

Soil quality indices calculations, based on major and minor elements for soils soil supporting mangroves at Al-Jubail Area, are given in Table 7. The values of $\mathrm{SQI}_{\mathrm{T}}$ and $\mathrm{SQI}_{\mathrm{MJ}}$ are similar means no effect of minor elements on status of soil quality of mangrove trees. All calculated SQI based on all parameters showed that high quality of soil supporting mangrove plants are at 
Am. J. Applied Sci., 6 (3): 498-506, 2009

Table 6: Mean values of major and minor elements as soil quality indicators to the soil supporting mangroves at Al-Jubail area, KSA

\begin{tabular}{|c|c|c|c|c|c|c|c|c|c|c|}
\hline \multirow[b]{2}{*}{ Sites } & \multicolumn{6}{|c|}{ Major elements (ppm) } & \multicolumn{4}{|c|}{ Minor elements (ppm) } \\
\hline & $\mathrm{Ca}$ & $\mathrm{Mg}$ & $\mathrm{K}$ & $\mathrm{Na}$ & $\mathrm{P}$ & $\mathrm{S}$ & $\mathrm{Cu}$ & $\mathrm{Zn}$ & $\mathrm{Fe}$ & $\mathrm{Mn}$ \\
\hline Control & 1.42 & 1.11 & 71.42 & 42.12 & 3.01 & 1.34 & 0.61 & 0.11 & 0.11 & 0.16 \\
\hline Sand mound & 3.31 & 4.43 & 110.11 & 121.91 & 3.23 & 1.66 & 2.89 & 1.53 & 0.86 & 0.45 \\
\hline Salt flat & 3.33 & 4.41 & 182.42 & 222.11 & 3.54 & 1.75 & 2.91 & 1.91 & 1.15 & 0.52 \\
\hline Shoreline & 3.32 & 4.45 & 344.43 & 232.00 & 3.95 & 1.77 & 3.92 & 2.18 & 1.28 & 0.55 \\
\hline Intertidal & 3.41 & 4.44 & 243.12 & 202.56 & 3.29 & 1.78 & 1.92 & 1.12 & 0.99 & 0.66 \\
\hline $\operatorname{LSD}_{P<0.5}$ & 0.12 & 1.11 & 54.12 & 20.11 & 0.12 & 0.21 & 22.11 & 2.44 & 1.15 & 0.11 \\
\hline
\end{tabular}

Control site means soil supporting healthy mangrove trees, other sites means soil supporting die off/die back mangrove trees.

LSD $=$ Least significant difference and $\mathrm{p}=$ Probability

Table 7: Mean values of soil quality indices based on major and minor elements as soil quality indicators to the soil supporting mangroves at Al-Jubail area, KSA

\begin{tabular}{lllllll}
\hline Sites & $\mathrm{SQI}_{\mathrm{T}}$ & $\mathrm{SQI}_{\mathrm{MJ}}$ & $\mathrm{SQI}_{\mathrm{MI}}$ & $\mathrm{SQI}_{3}$ & $\mathrm{SQI}_{1}$ & $\mathrm{SQI}_{{ }^{*}}$ \\
\hline Control & 1.00 & 1.00 & 1.00 & 1.00 & 1.00 & 1.00 \\
Sand mound & 0.48 & 0.48 & 0.17 & 0.19 & 0.35 & 0.64 \\
Salt flat & 0.29 & 0.29 & 0.15 & 0.12 & 0.19 & 0.39 \\
Shoreline & 0.20 & 0.20 & 0.14 & 0.08 & 0.18 & 0.21 \\
Intertidal & 0.26 & 0.26 & 0.21 & 0.10 & 0.21 & 0.29 \\
LSD $_{P<0.5}$ & 0.05 & 0.05 & 0.03 & 0.04 & 0.05 & 0.10 \\
\hline
\end{tabular}

Control site means soil supporting healthy mangrove trees, other sites means soil supporting die off/die back mangrove trees. $\mathrm{SQI}_{\mathrm{T}}=$ Soil quality index based on all soil properties, $\mathrm{SQI}_{\mathrm{MJ}}=$ Soil quality index based on all soil cations, $\mathrm{SQI}_{\mathrm{MI}}=$ Soil quality index based on all soil anions, $\mathrm{SQI}_{3}=$ Soil quality index based on $\mathrm{Na}, \mathrm{Ca}$ and $\mathrm{K}, \mathrm{SQI}_{1}=$ Soil quality index based on $\mathrm{Na}, \mathrm{SQI}_{1^{*}}=$ Soil quality index based on $\mathrm{K}$, LSD $=$ Least significant difference and $p=$ Probability

sand mound sites, while low quality are recorded at shoreline sites. Small variations between all studied sites were listed for $\mathrm{SQI}_{\mathrm{MI}}$. These data showed that $\mathrm{SQI}_{\mathrm{T}}, \mathrm{SQI}_{\mathrm{MJ}}$ and $\mathrm{SQI}_{1 *}$ are the best indicators for soil quality.

Problems relating to Avicennia marina grown at Al-Jubail Area are die off and die back plants, besides the non-germinating seeds. These problems may be due to continuous threats of land-filling and dredging which in turn affect the supply of oxygen to its root system and thereby prevent the normal root growth and efficient metabolic activity. Zonation patterns appear to be present in the mangrove at Al-Jubail. Pneumatophore height and density increase significantly towards the sea. Tree roots at the seaward edge may be oxygen- limited due to the mangrove mud being anoxic, where the presence of taller and more abundant pneumatophores rising above the mud will help transport oxygen to the submerged roots and by the development of internal gas transport pathways extending throughout the entire root system and communicating with the air by means of lenticels or other specialized water exuding structures ${ }^{[11]}$.

Soil quality is one of the most important factors in sustaining the global biosphere and developing sustainable agricultural practices ${ }^{[7]}$. It has been defined in several different ways in recent years from view points of bioproductivity, sustainability, environmental protection, and human and animal health. In this paper, soil quality refers to its capacity to meet the need of plant growth. Many practices greatly impact the direction and degree of soil quality changes in time and space. Understanding the effects of these practices on soil quality and its indicators has been identified as one of the most important goals for modern soil science and plant growth ${ }^{[7]}$. Soils at Al-Jubail Area are subjected to long-term damage and might gradually decrease its soil quality over the years. Major plants in the shoreline of the Arabian Gulf especially mangroves were subjected to continuous threats which include land-filling and dredging for coastal expansion; destructive fishing methods; impacts from tourism, shipping and maritime activities, sewage and other pollution discharges. Low biological activity (Table 2), high soluble cations and anions (Table 4) and major and minor elements (Table 6) may attribute to both decreased amount of organic substrate and the size of microbial biomass in soil ${ }^{[24,41]}$.

The lower percentage of active microbial biomass is also attributed to low organic amendment in soil and high soluble cations and anions and major and minor elements under above stresses. The low organic residue supply could reflect the low amount of readily available $\mathrm{C}$ in soil which functions as food and energy sources and drives efficient microbial activity ${ }^{[15]}$. Soil basal respiration and ratios of $\mathrm{CO}_{2}-\mathrm{C} \mathrm{C}_{\mathrm{org}}{ }^{-1}$ or $\mathrm{CO}_{2}-\mathrm{C} \mathrm{C}_{\mathrm{TMB}}{ }^{-1}$ give an indication of the metabolic activity of soil, which accounted for the recycling of organic $\mathrm{C}$ in low ${ }^{[9]}$.

The amount of $\mathrm{CO}_{2}-\mathrm{C}$ respired per unit microbial biomass $\mathrm{C}\left(\mathrm{qCO}_{2}\right)$ was large in high oxidative soils under these stresses due to low microbial biomass $\mathrm{C}$ pool and low biological activity ${ }^{[14,38]}$. This inferred that for a given amount of organic $\mathrm{C}$ in soil, proportionally more $\mathrm{C}$ would be assimilated through microbial biomass with the high $\mathrm{qCO}_{2}$ and the soils under stress would accumulate less $\mathrm{C}$ over time ${ }^{[6]}$. A high $\mathrm{qCO}_{2}$ was reported in less productive soil compared to more productive soil ${ }^{[12]}$ and continuous loss of $\mathrm{CO}_{2}$ from soil may indicate ecosystem inefficiency, that is, energy 
loss from the soil system ${ }^{[8]}$. High ecosystem respiration, $\mathrm{qCO}_{2}$ in soil may often result from stress and disturbance factors.

The physical breakdown of the aggregates due to stresses temporarily promotes the interaction between microbes and organic $\mathrm{C}$ substrates initially protected within the macro aggregates ${ }^{[22,38]}$. This process leads to increased microbial oxidation of the organic $\mathrm{C}$ and subsequently deplete the soil organic $C^{[23]}$. The data on microbial biomass $\left(\mathrm{C}_{\mathrm{TMB}}, \mathrm{C}_{\mathrm{AMB}}\right)$ and its activities $(\mathrm{BR}$, $\mathrm{qCO}_{2}, \mathrm{ARG}$ and DEA) in these soils are consistent with other findings that suggests the need for the management practices that could increase the proportion of soil organic $\mathrm{C}$ through microbial biomass $^{[2,14,28]}$. Consistent relationship between microbial biomass and activities in soil with water stability of soil particles were observed. This may effectively less protective organic $\mathrm{C}$ from microbial decomposition $^{[31]}$. From the obtained results (Table 2, 4 and 6), it is assumed that a low quality in the properties of soil of die off/die back mangroves may have been related to the decreasing in amount of high quality litter, decomposable organic $\mathrm{C}$ and efficient $\mathrm{C}$ assimilation through less beneficial effects of soil active microbial biomass. Low litter quality materials have been found to decompose and assimilate slower than high quality litter materials ${ }^{[20]}$.

\section{CONCLUSION}

The costal habitat diversity at Al-Jubail Area of Saudi Arabian coast of the Arabian Gulf supports different mangrove plant populations with various characteristics. These characters include die off/die back mangrove plants. This means that it is necessary to maintain the population of these communities at an optimal level.

\section{ACKNOWLEDGEMENT}

This study is part of the research activities of the Center of Excellence of Biodiversity Research program, developed and funded by the Ministry of Higher Education, KSA. Thanks are expressed to Center of Excellence and anonymous referees for their constructive comments on the first draft of this study.

\section{REFERENCES}

1. Alef, K. and D. Kleiner, 1987. Applicability of arginine ammonification as indicator of microbial activity in different soils. Biol. Fertility Soils, 5: 148-151. Doi: 10.1007/BF00257650. http://www.springerlink.com/content/km4q77u575 $1173 \mathrm{k} 4 /$.
2. Sparling, G.P., 1992. Ratio of microbial biomass carbon to soil organic carbon as a sensitive indicator of changes in soil organic matter. Aust. J. Soil Res., 30: 195-207. Doi: 10.1071/SR9920195. http:/www.publish.csiro.au/ paper/SR9920195.htm.

3. Anderson, T.H. and T.R.G. Gray, 1991. The Influence of Soil Organic C on Microbial Growth and Survival. In: Advances in Soil Organic Matter Research: The Impact of Agriculture and the Environment, Wilson, W.S. (Ed.), The Royal Society of Chemistry, Cambridge, UK, pp: 253-266. $\quad$ ISBN: $\quad \begin{array}{lllll}85573 & 813 & 9\end{array}$ http://www.woodheadpublishing.com/EN/book.asp $\mathrm{x}$ ?bookID=774.

4. Berger, U., M. Adams, V. Grimm and H. Hildenbrandt, 2006. Modeling secondary succession of neotropical mangroves: Causes and consequences of growth reduction in pioneer species. Perspectives in Plant Ecology. Evolut. Syst., 7: 243-252. Doi:10.1016/J.Ppees. 2005.08.001. http://www.sciencedirect.com/ science?_ob=ArticleURL\&_udi=B7GVV-H99990$1 \&$ _user $=10 \&$ _rdoc $=1 \&$ fmt $=\&$ orig $=$ search $\&$ _so $\mathrm{rt}=\mathrm{d} \& \mathrm{view}=\mathrm{c} \&$ _version $=1 \&$ _urlVersion $=0 \&$ _useri

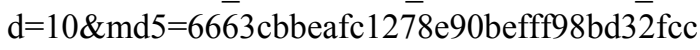

5. Peter, J.C., R.A. Kerrigan and C.J. Westphal, 2001. Dispersal potential and early growth in 14 tropical mangroves: do early life history traits correlate with patterns of adult distribution? J. Ecol., 89: 648-659. Doi: 10.1046/j.00220477.2001.00584.x http:/www3.interscience. wiley.com/journal/119015046/abstract?CRETRY= 1\&SRETRY $=0$.

6. Griffiths, B.S., 1994. Microbial-feeding nematodes and protozoa in soil: Their effects on microbial activity and nitrogen mineralization in decomposition hotspots and the rhizosphere. Plant and Soil, 164: 25-33. Doi: 10.1007/BF00010107. http://www.springerlink.com/content/13jn04580703 r60p.

7. Moebius-Clune, B.N., H.M. van Es, O.J. Idowu, R.R. Schindelbeck, D.J. Moebius-Clune, D.W. Wolfe, G.S. Abawi, J.E. Thies, B.K. Gugino, and R. Lucey, 2008. Long-term effects of harvesting maize stover and tillage on soil quality. Soil Sci. Soc. Am. J., 72: 960-969. Doi: 10.2136/ sssaj2007.0248. http://soil.scijournals.org/cgi/ content/abstract/72/4/960. 
8. Campbell, C.A., V.O. Biederbeck, B.G. McConkey, D. Curtin and R.P. Zentner, 1998. Soil quality-effect of tillage and fallow frequency. Soil organic matter quality as influenced by tillage and fallow frequency in a silt loam in southwestern Saskatchewan. Soil Biol. Biochem., 31: 1-7. DOI: 10.1016/S0038-0717(97)00212-5. http://www. sciencedirect.com/science?_ob=ArticleURL\&_udi $=$ B6TC7-3V5VNVB-1\&_user $=10 \& \_$rdoc $=1 \& \_\mathrm{fmt}$ $=\&$ orig $=$ search \& sort $=\mathrm{d} \&$ view $=\mathrm{c} \&$ version $=1 \&$ _urlVersion $=0 \& \_u s e r i d=10 \& \mathrm{md} 5=\mathrm{c} 6 \mathrm{~b} 206681 \mathrm{ba} 06$ f324f4051f5fd1e8a9e

9. Chander, K., S. Goyal, D.P. Nandal and K.K. Kapoor, 1998. Soil organic matter, microbial biomass and enzyme activities in a tropical agroforestry system. Biol. Fertility Soils, 27: 168-172. Doi: 10.1007/s003740050416 http://www.springerlink.com/content/wf47np79md $5 \mathrm{v} 4 \mathrm{p} 67 /$

10. Thampanya, U., J.E. Vermaat and J. Terrados, 2002. The effect of increasing sediment accretion on the seedlings of three common Thai mangrove species. Aquatic Botany, 74: 315-325. doi:10.1016/S0304-3770(02)00146-8 http://www. sciencedirect.com/science?_ob=ArticleURL\&_udi $=$ B6T4F-47242DJ-2\&_user $=10 \& \_$rdoc $=1 \& \_$fmt $=$ \&_orig $=$ search\&_sort $=\mathrm{d} \&$ view $=\mathrm{c} \& \_$version $=1 \& \_\mathrm{u}$ rlVersion $=0 \& \_$userid $=10 \& \mathrm{md} 5=36 \mathrm{cca} 788 \mathrm{c} 7 \mathrm{af3bd}$ 19c3286107f2e1b90

11. Dahdouh-Guebas, F., M. Verneirt, J.F. Tack, D.V. Speybroeck and N. Koedam, 1998. Propagule predators in Kenyan mangrove and their possible effect on regeneration. Marine Freshwater Res., 49: 345-350. doi: 10.1071/MF97108 http://www. publish.csiro.au/paper/MF97108.htm

12. Yoo, G. and M.M. Wander, 2008. Tillage effects on aggregate turnover and sequestration of particulate and humified soil organic carbon. Soil Sci. Soc. Am. J., 72: 670-676. DOI: 10.2136/sssaj2007.0110 http://soil.scijournals.org/ cgi/content/abstract/72/3/670

13. Doran, J.W. and T.B. Parkin, 1994. Defining and Assessing Soil Quality. In: Defining Soil Quality for a Sustainable Environment, Doran, J.W., D.C. Coleman, D.F. Bezdicek and B.A. Stewart, (Eds.). Special Publication 35. Soil Science Society of America, Madison, WI, USA. pp: 3-22. ISBN: 9780891188070

http://www.amazon.com/Defining-Soil-QualitySustainable-Environment/dp/089118807X
14. Marinari, S., R. Mancinelli, E. Campiglia and S. Grego, 2006. Chemical and biological indicators of soil quality in organic and conventional farming systems in Central Italy. Ecol. Indicators, 6: 701-711. doi:10.1016/j.ecolind.2005. 08.029 http://www.sciencedirect.com/science? $\mathrm{ob}=$ ArticleURL\&_udi=B6W87-4H6XM2K-3\& user $=10 \& \_$rdoc $=1 \&$ fmt $=\&$ orig $=$ search \&_sort $=\mathrm{d}$ \&view $=c \&$ _version $=1 \&$ urlVersion $=0$ \&_userid $=1$ 0\&md5=edfb93bddd4c815446423173c07f51f1

15. Acosta-Martínez, V., S. Klose and T.M. Zobeck, 2003. Enzyme activities in semiarid soils under conservation reserve program, native rangeland, and cropland. J. Plant Nut. Soil Sci., 166: 699-707. Doi:10.1002/jpln.200321215 http://www3. interscience.wiley.com/journal/106570914/abstract ?CRETRY $=1 \&$ SRETRY $=0$

16. Humphreys, G.S. and M.T. Wilkinson, 2007. The soil production function: A brief history and its rediscovery. Geoderma, 139: 73-78.doi:10.1016/j. geoderma.2007.01.004 http://www.sciencedirect. com/science? ob=ArticleURL\&_udi=B6V67$4 \mathrm{~N} 2 \mathrm{D} 63 \mathrm{~W}-1$ \&_user $=10 \& \_$rdoc $=1 \& \_\mathrm{fmt}=$ \&_orig $=$ search\&_sort $=\overline{\mathrm{d}} \&$ view $=\mathrm{c} \&$ _version $=1$ 1\&_urlV $\overline{\mathrm{V}}$ ersio $\mathrm{n}=0$ \&_userid $=10 \& \mathrm{md} 5=5 \mathrm{f} 2 \mathrm{f} 8 \mathrm{c} 93 \mathrm{c} 839 \mathrm{~b} 730 \mathrm{bffb} 910$ $99 \mathrm{~b} 240 \mathrm{f} 2 \mathrm{~d}$

17. Insam, H. and K.H. Domsch, 1988. Relationship between soil organic carbon and microbial biomass on chronosequences of reclamation sites. Microbial Ecol., 15: 177-188. Doi: 10.1007/BF02011711 http://www.springerlink.com/content/k575g264846 $14492 /$

18. Lovell, R.D., S.C. Jarvis and R.D. Bardgett, 1995. Soil microbial biomass and activity in long-term grassland: Effects of management changes. Soil Biol. and Biochemistry, 27: 969-975. doi:10. 1016/0038-0717(94)00241-R http://www. sciencedirect.com/science?_ob=ArticleURL\&_udi 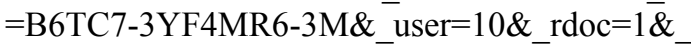 $\mathrm{fmt}=\& \_$orig $=$search\&_sort $=\mathrm{d} \&$ view $=\overline{\mathrm{c} \&} \_\mathrm{acct}=\overline{\mathrm{C}} 00$ $0050221 \&$ version $=1 \&$ urlVersion $=0 \&$ userid $=10$ $\& \mathrm{md} 5=133 \mathrm{~d} 0 \mathrm{dec} 4 \mathrm{ad} 85 \mathrm{~d} 79 \mathrm{c} 1 \mathrm{fbd} 0501 \mathrm{f} 805 \mathrm{bbb}$

19. Krauss, K.W. and J.A. Allen, 2003. Influences of salinity and shade on seedling photosynthesis and growth of two mangrove species, Rhizophora mangle and Bruguiera sexangula, introduced to Hawaii. Aquatic Botany, 77: 311-324. doi:10.1016/j.aquabot.2003.08.004 http://www. sciencedirect.com/science?_ob=ArticleURL\&_udi $=$ B6T4F-4B0PB53-8\&_user $=10 \& \_$rdoc $=1 \& \_$fmt $=\&$ orig $=$ search\&_sort $=\mathrm{d} \&$ view $=\mathrm{c} \& \_$version $=1 \&$ _urlVersion $=0 \& \_$userid $=10 \& \mathrm{md} 5=35 \mathrm{ca} 7 \mathrm{cdd} 6982 \mathrm{f}$ $\overline{c b b 3 f 6920 f 286 a \overline{4} 5 \mathrm{ec} 2}$ 
20. Domisch, T., L. Finér, J. Laine and R. Laiho, 2006. Decomposition and nitrogen dynamics of litter in peat soils from two climatic regions under different temperature regimes. Eur. J. Soil Biol. , 42: 74-81. doi:10.1016/j.ejsobi.2005.09.017 http://www. sciencedirect.com/science?_ob=

ArticleURL\&_udi=B6VR7-4HD88PP-1\&_user= $10 \& \_$rdoc $=1 \&$ fmt $=\& \_$orig $=$search\&_sort $=\mathrm{d} \&$ view $=$ c\&_acct $=C 000050221 \&$ _version $=1 \&$ urlVe rsion $=0 \&$ userid $=10 \& \mathrm{md} 5=5 \mathrm{e} 04 \mathrm{fa} 1 \mathrm{~d} 1 \mathrm{f} 7015 \mathrm{cdcf} 5$ $439 \mathrm{c} 5 \mathrm{c} 50844 \mathrm{ca}$

21. Ye, Y., N.F.Y. Tam, Y.S. Wong and C.Y. Lu, 2003. Growth and physiological responses of two mangrove species (Bruguiera gymnorrhiza and Kandelia candel) to waterlogging. Environ. Exp. Botany, 49: 209-221.DOI: 10.1016/S00988472(02)00071-0. http://www. sciencedirect.com/ science?_ob=ArticleURL\&_udi=B6T66-47RBFPH $-2 \& \_u s e r=10 \& \_r d o c=1 \& \_$fmt $=\& \_$orig $=$search $\&$. sort $=\mathrm{d} \&$ view $=$ c\&_version $=1 \& \_$urlVersion $=0 \& \_$us erid $=10 \& m d 5=02 b 9 a 3154 \mathrm{fb} 7737 \mathrm{~d} 7 \mathrm{e} 1 \mathrm{~b} 4 \mathrm{bc} 27372 \mathrm{f}$ 567.

22. Feller, I.C. and K.L. McKee, 1999. Small gap creation in Belizean mangrove forests by a woodboring insect. Biotropica, 31:607-617. Doi: 10.1111/j.1744-7429.1999.tb00408.x. http:// www3.interscience.wiley.com/journal/119058122/ abstract?CRETRY $=1 \&$ SRETRY $=0$

23. Molope, M.B., I.C. Grieve and E.R. Page, 1987. Contributions by fungi and bacteria to aggregate stability of cultivated soils. European Journal of Soil Science, 38: 71-77. Doi: 10.1111/j.13652389.1987.tb02124.x. http://www3.interscience. wiley.com/journal/120023703/abstract.

24. Dick, R.P., 1992. A review: long-term effects of agricultural systems on soil biochemical and microbial parameters. Agric. Ecosyst. Environ., 40: 25-36. doi:10.1016/0167-8809(92)90081-L http://www.sciencedirect. com/science?_ob= ArticleURL\&_udi=B6T3Y-48XDK36-14\&_user= $10 \& \_\mathrm{rdoc}=1 \&$ fmt $=$ \&_orig $=$ search\&_sort $=\mathrm{d} \&$ vie $\mathrm{w}=\mathrm{c} \& \_\mathrm{acct}=\mathrm{C} 000050221 \&$ \&version $=1$ \&_urlVersio $\mathrm{n}=0$ \&_userid $=10 \& \mathrm{md} 5=941 \mathrm{fe} 58632 \mathrm{c} 53 \mathrm{a} 4 \mathrm{~b} 16 \mathrm{a} 7 \mathrm{c} 0$ $17 \mathrm{c} 018 \mathrm{f} 53 \mathrm{~b}$

25. Francis, A.P. and D.J. Currie, 2003. A globally consistent richness-climate relationship for angiosperms. Am. Nat. 161: 523-536. DOI: 10.1086/368223 http://www.journals.uchicago. edu/doi/abs/10.1086/368223? journalCode=an
26. Agrawal, A. and C.C. Gibson, 1999. Enchantment and disenchantment: The role of community in natural resource conservation. World Dev., 27: 629-649. Doi: 10.1016/S0305-750X(98)001612 http://www.sciencedirect.com/science?_ob= ArticleURL\&_udi=B6VC6-3X5H9MH-G\&_user= $10 \& \_$rdoc $=1 \& \_\mathrm{fmt}=$ \&_orig $=$ search\&_sort $=\mathrm{d} \& \mathrm{vie}$ $\mathrm{w}=\mathrm{c} \&$ _acct $=\mathrm{C} 000050221 \&$ _version $=1 \&$ urlVersio $\mathrm{n}=0 \&$ userid $=10 \& \mathrm{md} 5=80$ eed $758929 \mathrm{~d} 2906 \mathrm{fffla} 7$ 6c9a56a368

27. Palma, R.M., N.M. Arrigo, M.I. Saubidet and M.E. Conti, 2000. Chemical and biochemical properties as potential indicators of disturbances. Biol. Fert. Soils, 32: 381-384. Doi: 10.1007/s003740000266 http://www.springerlink. com/content/xayj0ar8w2d655f3/

28. Brookes, P.C., 1995. The use of microbial parameters in monitoring soil pollution by heavy metals. Biology and Fertility of Soils, 19: 269-279. Doi: 10.1007/BF00336094 http://www.springerlink .com/content/rj92gq302327gl5k/

29. Rasmussen, K.J. and M.A. Arshad, 1999. Impact of ploughless soil tillage on yield and soil quality: a Scandinavian review. Special Issue: Tillage and soil quality. Soil Tillage Res., 53: 3-14. doi:10.1016/S0167-1987(99)00072-0 http://www. sciencedirect.com/science?_ob=ArticleURL\&_udi $=$ B6TC6-3XY25R9-2\&_user $=10 \& \_$rdoc $=1 \& \_\mathrm{fmt}=$ \&_orig $=$ search\&_sort $=\mathrm{d} \& \mathrm{view}=\mathrm{c} \& \_v e r s i o n=1 \& \_\mathrm{u}$ rlVersion $=0 \&$ userid $=10 \& \mathrm{md} 5=214442 \mathrm{be} 8757 \mathrm{~d} 8 \mathrm{e}$ $12275423 \mathrm{bb} 13 \mathrm{db} 34 \mathrm{~b}$

30. Richards, L.A., 1969. Diagnosis and improvement of saline and alkali soils. AgriculturalHandbook. No. 60. Superintendent of Documents, Government Printing Office, Washington. ISN:3722 http://library.wur.nl/isric/index2.html? url=http://library.wur.nl/WebQuery/isric/3722

31. Liu, A., B.L. Ma and A.A. Bomke, 2005. Effects of cover crops on soil aggregate stability, total organic carbon, and polysaccharides. Soil Sci. Soc. Am. J., 69: 2041-2048. DOI: 10.2136/sssaj2005.0032. http://soil.scijournals.org/ cgi/content/abstract/69/6/2041.

32. Bond, C.A. and Y.H. Farzin, 2008. Agroecosystem modeling and optimal economic decisions: Implications for sustainable agriculture. Optimal Control Applications and Methods, 29: 59-80. Doi: 10.1002/oca.817 http://www3.interscience.wiley. com/journal/114297436/abstract?CRETRY=1\&SR $\mathrm{ETRY}=0$ 
33. Farnsworth, E. 2000. The ecology and physiology of viviparous and recalcitrant seeds. Ann. Rev. Ecol. Syst., 31: 107-138. Doi: 10.1146/annurev. ecolsys.31.1.107. http://arjournals.annualreviews. org/doi/abs/10.1146/annurev.ecolsys.31.1.107?coo kieSet $=1$ \&journalCode $=$ ecolsys. 1

34. Clarke, P.J. and R.A. Kerrigan, 2002. The effects of seed predators on the recruitment of mangroves. J. Ecol., 90: 728-736. Doi: 10.1046/j.13652745.2002.00705.x http://www3.interscience. wiley.com/journal/118909412/abstract

35. Tabatabai, M.A., 1994. Soil Enzymes. In: Methods of Soil Analysis, Part II, Microbiological and Biochemical Properties, Weaver, R.W., J.S. Angle and P.S. Bottomley (Eds.) SSSA Book Series 5, pp: 775-833. Soil Science Society of America, Inc. ISBN:0-89118-810-X

36. Naidoo, G., H. Rogalla and D.J. von Willert, 1997. Gas exchange responses of a mangrove species, Avicennia marina, to waterlogged and drained conditions. Hydrobiologia, 352: 39-47. Doi: 10.1023/A:1003088803335. http://www. springerlink.com/content/p922439182337325/

37. Tomlinson, P.B., 1995. The Botany of Mangroves. Cambridge University Press, Cambridge, UK. ISBN-10: 052146675X

38. Jithesh, M. N., S.R. Prashanth, K.R. Sivaprakash and A. Parida, 2006. Monitoring expression profiles of antioxidant genes to salinity, iron, oxidative, light and hyperosmotic stresses in the highly salt tolerant grey mangrove, Avicennia marina (Forsk.) Vierh. by mRNA analysis. Plant Cell Rep., 25: 865-876. Doi: 10.1007/s00299-0060127-4 http://www.springerlink.com/content/ e7gp850286457486/
39. Ukpong, I.E., 1997. Vegetation and its relation to soil nutrient and salinity in the Calabar mangrove swamp, Nigeria. Mangrove Salt Marshes, 1: 211-218. Doi: 10.1023/A:1009952700317. http://www. springerlink.com/content/v04477lqk781353q/

40. Blagodatsky, S.A., O. Heinemeyer and J. Richter, 2000. Estimating the active and total soil microbial biomass by kinetic respiration analysis. Biol. Fertility Soils, 32: 73-81. Doi: 10.1007/s003740000219. http://www.springerlink. com/content/dntkpux7uwqnxkwv/

41. Janzen, H.H., C.A. Campbell, R.C. Izaurralde, B.H. Ellert, N. Juma, W.B. McGill and R.P. Zentner, 1998. Management effects on soil C storage on the Canadian prairies. Soil Tillage Res., 47: 181-195. doi:10.1016/S0167-1987(98)00105-6 http://www.sciencedirect.com/science?_ob=Article URL\&_udi=B6TC6-3V4KP4W-16\&_user $=10 \&$ 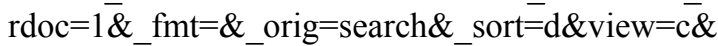 _version $=1 \&$ \&urlVersion $=0 \&$ userid $=10 \& \mathrm{md} 5=03$ $\overline{0} 16 \mathrm{e} 838 \mathrm{c} 4 \mathrm{e} 7 \overline{6} 3 \mathrm{~b} 7136 \mathrm{fba} 23 \mathrm{f} 7 \overline{1} 5 \mathrm{~d} 9 \mathrm{f}$

42. Wang, X. and Z. Gong, 1998. Assessment and analysis of soil quality changes after eleven years of reclamation in subtropical China. Geoderma, 81: 339-355. Doi: 10.1016/S0016-7061(97)00109-2 http://www.sciencedirect.com/science?_ob=Article URL\&_udi=B6V67-3SX70N3-9\&_user $=10 \&$ 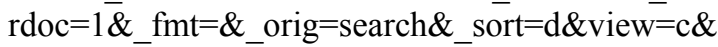 _version $=1 \&$ \&urlVersion $=0 \&$ userid $=10 \& \mathrm{md} 5=\mathrm{a} 7$ 46ba277c70dd83c7d95c2852faff35. 